\title{
RESUME MATERI HUKUM TATA NEGARA
}

Nama :M.Saldy

Nim : :10200120140

Pembahasan :

\section{Hukum Tata Negara?}

Istilah Hukum Tata Negara, ialah hasil terjemahan dari beberapa Bahasa misalnya Bahasa belanda "staatsrecht" ,dalam Bahasa inggris "constitutional law", dalam Bahasa jerman "Verfassubgrecht",dan dalam Bahasa perancis disebut "Droit Constituionnel".

Berbagai pendapat mengenai definisi hukum tata negara. Dan berdasarkan berbagai pendapat itu, kita dapat melihat beberapa perbedaan dan persamaan pendapat. Sehingga, pengertian Hukum Tata Negara dapat dikatakan bahwa hukum tata negara merupakan sebuah peraturan yang mengatur mengenai penyelenggaraan pemerintahan yang dijalankan oleh pejabat atau alat alat negara/ Lembaga negara.

Hukum Tata Negara merupakan cabang struktur dan juga mekanisme kenegaraan serta hubungan struktur dan mekanisme negara dan warga negara. Ruang lingkup struktur umum dari negara sebagai suatu organsasi, yaitu :

1. Bentuk negara (kesatuan atau federasi)

2. Bentuk pemerintahan (kerajaan atau republik)

3. System pemerintahan (presidential, parlementer, monarki absolute)

4. Corak pemerintahan (dictator praktis, nasionalis, liberal, demokrasi)

5. System pendelegasian kekuasaan negara (desentralisasi, meliputi jumblah, dasar, cara dan hubungan antara pusat dan daerah)

6. Gafris-garis besar tentang organissi pelaksanaan (peradilan, pemerintahan, perundangan)

7. Wilayab negara ( darat, laut, udara)

8. Hubungan antara rakyat dengan negara.

9. Cara-cara rakyat menjalankan hak-hak ketatanegaraan.

10. Dasar negara misslnya arti dari Pancasila,hubungan Pancasila dengan kaidah-kaidah hukum, dll.

11. Ciri-ciri lahir dan kepribadian negara misalnya lagu kebangsaan, Bahasa,lambing , bendera, dll.

Hubungan Hukum Tata Negara dan ilmu-ilmu yang lain. Misalnya, ilmu negara. Ilmu negara dan Hukum Tata Negara ialah konsentrasi ilmu atau pengetahuan yang memiliki hubungan yang cukup erat. Dikarenakan hal ini didasari oleh, persamaan objek dalam pengkajiannya contohnya negara.

Kata umum yang menunjukkan dasar kajian dari ilmu negara mencakup hal-hal umum, misal teori terbentuknya negara beserta sifat,unsur serta fungsi dan tujuannya yang merupakan 
bentuk dari asas-asas pokok. Untuk itu hal ini yang membuat ilmu negara memiliki hubungan dengan Hukum Tata Negara.

\section{Sumber-Sumber Hukum Tata Negara}

Sumber hukum merupakan semua hal yang menimbulkan aturan-aturan yang memiliki kekuatan yang memaksa, mengikat, dan apabila aturan tersebut dilanggar terdapat sanksi yang tegas. Utrech 'pengantar hukum indonesia' mengatakan bahwa kebanyakan para ahli memberikan istilah sumber hukum berdasarkan sudut pandang keilmuannya. Yakni;

1. Sumber hukum dari sudut pandang ahli sejarah

2. Sumber hukum dari sudut para ahli filsafat

3. Sumber hukum ditinjau dari sudut para ahli sosiologi

4. Sumber huum dari sudut ahki ekonomi

5. Sumber hukum dari sudut ahli religious

6. Sumber hukum dari sudut pandang ahki hukum.

Sumber Hukum Tata Negara dapat juga diartikan sebagai tempat dan juga sebagai asalnya Hukum Tata Negara. Sumber sebagai tempat misalnya, orang yang mengatakan bahwa presiden dan wakil presiden republik Indonesia itu harus orang Indonesia asli atau dipilih secara langsung oleh rakyat. Sedangkan contoh sumber sebagai asalnya adalah undang-undang, yang berwenang mengeluarkan/menetapkannya adalah presiden dengan persetujuan DPR.

Dalam hukum tata negara di Indonesia juga bersumber pada sumber hukum materil (Pancasila). Pancasila merupakan sumber hukum materil bagi semua hukum yang ada di Indonesia. Begitu juga dengan sumber hukum tata negara. Nilaia-nilai Pancasila menjadi inspirasi dan juga sebagai bahan atau materi dalam menyusun semua peraturan Hukum Tata Negara. Sekaligus sebagai alat penguji setiap perturan Hukum Tata Negara yang berlaku, baik yang bertentangan ataupun tidak seperti yng tercantum dalam ketetapan MPR no. 1ll/20oo Pasal 1,2,3, serta UU. No. 12 tahun 2012 Pasal 2. Formil (UUD 1945) UUD 1945 sebagai hukum dasar tertulis merupakan bentuk peraturan perundang-undangan tertinggi yang menjadi dasar dan sumber (formil) untuk semua peraturan perundang-undangan yang mengatur ketatanegaraan Indonesia seperti yang tercantum dalam ketetapan MPR no. 1ll/20oo Pasal 3, serta UU. No. 12 Tahun 2011 Pasal 3. Bentuk dan tata urutan perundangan sebagai bagian dari sumber formil htn Indonesia (UU. No. 12 tahun 2011 Pasal 7) antara lain:

1. Undang-undang dasar 1945

2. Ketetapan mpr (tap mpr)

3. Undang-undang (uu)/peraturan pemerintah pengganti undang-undang (perpu).

4. Peraturan pemerintah (pp)

5. Peraturan presiden (perpres)

6. Peraturan daerah (perda)

7. Perda provinsi

8. Perda kota/kabupaten

9. Peraturan desa

10. Konvensi 
Traktat (perjanjian internasional), yang terakhir menjadi sumber dari hukum tata negara adalah traktat atau biasa juga disebut perjanjian internasional. Perjanjian internasional (bilateral maupun multilateral) yang terkait dengan hukum tata negara suatu negara. Misalnya, traktat, Asean, UDHR PBB.

\section{Asas-asas hukum tata negara}

Istilah asas menurut KBBI ialah petunjuk atau landasan memberi arah untuk bagaimana mempelajari materi perkuliahan yang akan membahas terkait Hukum Tata Negara dan sebagai dasar, pedoman, atau sesuatu yang menjadi pokok dasar. Tentang ketatanegaraan yang harus dilihat dari UUD yang merupakan hukum positif dan merupakan konstitusi hukum dasar dan juga sebagai pondasi dari berdirinya suatu negara sesuai ideologi negara.

Fungsi asas hukum terbagi atas dua,yakni sebagai penjaga konsistensi dan mengatasi konflik.

Adapun asas-asas pemberlakuan Hukum Tata Negara dalam rana Indonesia ialah sebagai berikut

- Asas Pancasila

Pancasila sering disebut dengan falsafah Negara dan ideologi Negara.Namun,dalam hal ini Pancasila digunakan sebagai dasar mengatur pemerintahan negara yang artinya setiap tindakan masyarakat Indonesia harus sesuai dengan Pancasila yang sudah ditetapkan sebagai dasar negara. Pancasila dipandang sebagai dasar negara Indonesia karena mencakup lima asas yaitu

- Asas ketuhanan yang maha esa

- Asas perikemanusiaan

- Asas kebangsaan

- Asas kedaulatan rakyat

- Asas keadilan social

- Asas Negara Hukum

Konsep negara hukum berkembang dalam dua system hukum, yaitu system Eropa continental dengan istilah Rechtaat yang dipelopori oleh Immanuel Kant dan Frederich Julius Stahl serta sistem Anglo-Saxon Rule Of Law yang dipelopori oleh A.V. Dicey.

Indonesia pada tahun 1945 pernah mendeklarasikan diri sebagai Negara Hukum terbukti dalam UUD Negara Republik Indonesia Pra-amandemen menyatakan, "Indonesia adalah negara yang berlandaskan hukum dan bukan negara yang berdasarkan kekuasaan belaka".kemudian dipertegas juga dalam UUD negara republic Indonesia hasil amandemen dalam pasal 1 ayat 3 bahwa "Indonesia adalah negara hukum".

- Asas negara kesatuan 
Asumsi negara kesatuan menyatakan bahwa tidak boleh ada negara dalam satu negara yang secara tegas dijelaskan dalam pasal 1 ayat (1) bahwa negara Indonesia ialah negara kesatuan yang berbentuk Republik. Asas ini merupakan prinsip dasar bahwa negara berdaulat sebagai satu kesatuan.

- Asas kedaulatan rakyat dan demokrasi

Dalam rumusan pasal 1 (ayat) 2 tersebut meneguhkan konsep kekuasaan tertinggi dalam bernegara adalah kehendak rakyat yang dilaksanakan dengan mekanisme kenagaraan berdasarkan konstituti. Berbeda dengan rumusan pasal sebelum dilakukan amandemen uud, dimana kedaulatan rakyat dijalankan sepenuhnya oleh majelis permusyawaratan rakyat.

- Asas pemisahan kekuasaan dan check and balances

Struktur kelembagaan negara, pergeseran kewenangan, perimbangan kekuasaan, penguatan sistem presidensil, perubahan sistem pemilihan presiden dan wakil presiden, dan pembentukan Lembaga negara baru, yang bertujuan untuk memperkuat penerapan prinsip saling m,engimbangi dan saling control ( check and balances).

\section{Sejarah Ketatanegaraan}

Sejarah ketatanegaraan Indonesia pernah memberlakukan sitem pemerintahan presidensil maupun parlemnter, tetapi juga karena dalam pelaksanaan kedua sistem ini sering menimbulkan permasalahan ketidaktegasan terhadap sistem yang diberlakukan. Pada awal kemerdekaan, terlepas dari kondisi darurat dan sifat kesementaraanya. Undang-undang dasar yang ditetapkan panitia persiapan kemerdekaan Indonesia pada tanggal 18 agustus 1945 mengatur dengan tegas bahwa sistem pemerintahan menganut sistem presidensil. Hal ini dibuktikan dengan adanya ketentuan bahwa presiden adalah sebagai kepala negara dan sekaligus sebagai kepala pemerintahan. Dan dalam menjalankan tugasnya dibantu oleh wakil presiden. Dalam hal ini tidak bertanggung jawab kepada dewan perwakilan rakyat. Disamping itu, presiden juga dibantu oleh mentri-mentri ,dimana mentri tersebut tidak bertanggung jawab atas dewan perwakilan rakyat, tetapi bergantung kepada presiden. Undang-undang dasar 1945 memberikan wewenang tertentu kepada presiden dalam menjalankan tugas pemerintahan. Demikian pemberi wewenang tersebut tidak ikut dengan Batasan-batasan terhadap penggunanya.

Dalam rapat pertama panitia persiapan kemerdekaan Indonesia pada tanggal 18 agustus 1945 menyatakan bahwa undang-undang dasar 1945 adalah undang-undang dasar kilat.

\section{UUD 1945 "sementara"}

Pada tanggal 18 agustus 1945 soekarno adalah rovolutie groundwet, nanti kita akan memiliki uud yang lebih baik. Dan ratulangi uud 1945 perlu disempurnakan. Aturan tambahan pasal 11 dalam 6 bulan setelah majelis permusyawaratan rakyat ini terbentuk, majelis bersidang untuk menetapkan undang-undang dasar. UUD 1945 yang 'sementara' dan sering disebut ;uud darurat', terbukti belum pasti mengenai sistem presidensial dalam uud 1945 dilaksanakan 
dengan dibentuknya cabinet pertama dibawah tanggung jawab presiden soearno pada tanggal 2 september 1945. Tetapi pada tanggal 14 november 1945 pemerintah mengeluarkan maklumat yang berisi perubahan cabinet dari sistem presidensil ke parlementer.

\section{Konstitusi republic Indonesia serikat (ris) 1949}

- Serangan omeom 1 maret 1949 di Jogjakarta ,

- Perang dunia ll berakhir; jepang menjadi negara kalah perang.

- Kerjaan belanda hendak kembali menjajah dengan taktik mendirikan negara kecil di sumatera, negara Indonesia timur, negara pasundan, nehgara jawa timur, dsb serta melancarkan agresi militer 1 (1947) dan agresi 11 (1948).

\section{Undang-undang dasar sementara 1950}

Negara ris tidak bertahan lama. Negara republic Indonesia,negara Indonesia timur, dan negara sumatera timur menggabungkan diri menjadi satu wilayah republic Indonesia. 19 mei 1950 pemerintah ris dan pemerintah ri sepakat membentuk kembali nkri dibentuk panitia untuk merancang uud. Perubahan ris menjadi uuds yang resmi berlaku 17 agustus 1950 dengan uu faderal no. 7 tahun 1950. Dasarnya yaitu pasal 134 uuds : konstituante Bersama pemerintah menyusun suatu uud ri yang akan mengganti uud 1950.

\section{Pemilihan umum 1955 : memilih konstituante}

Dalam kurung waktu 3 tahun (1956-1959) konstituante berhasil merumuskan sejumlah pasal, tapi mengalami kebuntuan dalam dasar negara. Desember 1955 pemilu memilih konstituante untuk mmebentuk uud. 1956-1959 konstituante bersidang dengan maksud membua uud yang tetap.

\section{Dektrit presiden 5 juli 1959}

Dimana presiden soekarno menyimpulkan majelis konstituante gagal, ia mengeluarkan dekrit 5 juli 1959 yaitu membubarkan konstituante dan memberlakukan kembali uud 1945.

\section{Konstitusi sebagai objek kajian hukum tata negara}

Konstitusi atau undang-undang dasar adalah suatu yang sagat penting dan mendasar atau fundamental untuk negara. Dalam konstitusi diatur masalah pokok bagi kehidupan bangsa dan negara. Hal-hal yang diatur dalam konstitusi antara lain tentang bentuk negara, dasar negara, ideologi negara, sistem pemerintahan, sistem kepartaian serta hak-hak warga negara.

Istilah konstitusi sebagian besar belum memahami apa makna istilah konstitusi dan berasal dari mana. Konstitusi berasal dari Bahasa perancis "constituere" artinya menetapkan atau membentuk. Pemakaian istilah konstitusi dimaksud sebagai pembentukan atau penyusunan negara. 
Dalam ketatnegaraan istilah konstitusi di berbagai negara telah banyak dipergunakan. Misalnya di belanda 'Contitutie' disamping kata 'ground wet' inggris 'constitution' dalam istilah sehari-hari konstitusi sering disamakan dengan undang-undang dasar yang merupakan terjemahan dari groundwet dalam Bahasa belanda (griund artinya dasar, wet artinya undangundang).

Konstitusi itu lebih luas dari UUD. Pengertian ini dikemukakan oleh Herman Heller dalam bukunya ajaran kostitusi sebagaimana dikutip oleh Moh. Koesnardi dan Bintan saragih (1994:140-1941) yang membagi konstitusi dalam 3 tingkat, yaitu :
a. Konstitusi sebagai pengertian sosial politik
b. Konstitusi sebagai pengertian hukum
c. Konstitusi sebagai suatu peraturan hukum, yakni peraturan hukum yang tertulis.

\section{Organ dan fungsi kekuasaan negara}

Pada umumnya, doktrin pemisahan kekuasan seperti yang dibayangkan oleh monstesquite itu, dianggap oleh para ahli sebagai pandangan yang tidak realistis dan jauh dari kenyataan . pandangannya itu dianggap oleh para ahli sebagai kekeliruan Montesquieu dalam memahami sistem ketatanegaraan inggris yang dijadikannya objek telaah untuk mencapai kesimpulan mengenai trias politica-nya itu dalam bukunya . tidak ada satu negara pun didunia yang sungguh-sungguh mencerminkan gambaran Montesquieu tentang pemisahan kekuasaan.

Istilah pemisahan kekuasaan itu sendiri konsep yang bersifat umum, seperti halnya konsep pembagian kekuasaan juga dipakai oleh banyak sarjana dengan pengertian-pengertian yang berbeda-beda satu dan yang lain. Arthur Mass membedakan pengertian pembagian kekuasaan tersebut kedalam dua pengertian yaitu (i) capital divisionof power, dan (ii) territorial division power, pengertian yang pertama bersifat fungsional, sedangkan yang kedua bersifat kewilayahan atau kedaerahan. Dengan demikian dapat dibedakan penggunaan kekuasaan itu dalam dua konteks yang berbeda, yaitu kekuasaan horizontal dan vertical.

Salah satu ciri negara hukum, yang dalam Bahasa inggris disebut but legal state atau state based on the rule of law, dalam bahsa belanda dan jerman disebut rechtsstaat, adalah adanya ciri pembatasan kekuasaan dalam penyelenggaraan kekuasaan negara. Meskipun kedua istilah rechtstaat dan rule of law itu memiliki latar belakang sejarah yang berbeda, tetapi sama-sama mengandung ide pembatasan kekuasaan. Pembatasan itu dilakukan dengan hukum yang kemudian menjadi ide dasar paham konstitusionalisme modern. Karena itu konsep negara hukum juga disebut sebagai negara konstituonal yaitu negara yang dibatasi oleh konstitusi . dalam konteks yang sama, gagasan negara demokrasi atau kedaulatan rakyat disebut pula dengan kstilah constituonal democracy yang dihubunglan dengan pengertian negara demokrasi yang berdasrkan atas hukum.

Menurut mountesquieu membagi kekuasaan negara menjadoi tiga cabang; yaitu, (i) kekuaaan legislative sebagai pembuat undang-undang (ii) kekuasaan eksekutif yang melaksanakan dan (iii) kekuasaan untuk menghakimi atau yudikatif. Dari ini dikenal sebgai 
pembagian kekuasaan modern dalam tiga fungsi, yakni legiskatif ( the legislative function), eksekutif ( the eksekutif or administrasive function), dan yudisial (the judicial function).

Disamping itu, dalam studi ilmu administrasi dikenal pula adanya teori yang membagi kekuasaan ke dalam dua fungsi. Dimana semua usaha membedakan dan membagi serta memisah-misahkan fungsi-fungsi kekuasaan itu ke dalam beberapa cabang, pada pokoknya adalah dalam rangka membatasi kekuasaan itu sendiri sehingga tidak menjadi sumber kesewenang-wenangan. 